\title{
PATIENT TRUST THROUGH THE ROLE OF MEDICAL STAFF OF GOVERNMENT-OWNED REGIONAL GENERAL HOSPITALS
}

\author{
Hadiyati \\ hadiyati@unilak.ac.id \\ Bambang Suroto \\ Universitas Lancang Kuning \\ Jalan Yos Sudarso No.KM. 8, Rumbai, Pekanbaru, Riau 28266 \\ Eddy Jusuf \\ Universitas Pasundan \\ Jl. Dr. Setiabudi No.193, Gegerkalong, Bandung, Jawa Barat 40153 \\ received: 30/10/19; revised: 12/12/19; published: 31/12/19
}

\begin{abstract}
Government-owned regional general hospitals are not the only hospitals in a region. Competition with private and foreign hospitals requires government-owned hospitals toimprove. The question is whether the role of medical staff is able to increase patient satisfaction and trust. This quantitative research was conducted in M. Sani Regional General Hospital in Tanjung Balai Karimun Regency, Riau Islands Province. The data were collected using questionnaires from 100 patients or families of inpatients totaling and taken using accidental sampling. The data were analyzed quantitatively using SEM analysis tools. The results showed that the variables of responsiveness and motivation given by the medical staff to patients had a significant and positive influence on patient satisfaction and had an impact on patient trust in the services provided by the hospital.
\end{abstract}

Keywords: responsiveness; motivation to patients; satisfaction and trust; inpatients

\section{INTRODUCTION}

Service productsare currently a mainstay as regions that have minimal natural resources take development efforts in service products. The development of the service products becomes very dynamic because consumer behavior as the basis of the service itself is actively studied by academics. One of the services is health services. Health needs have developed into basic needs and the improvement of people's welfare in terms of health that has drawn the attention of individuals, governments, and the world. In addition, the marketing of health service products also continues to grow along with the dynamic behavior of the consumers who have better knowledge due to technology, more developed insights, and better degree of life.

Hospitals become an important part of the marketing of health services. Government and private hospitals continue to compete to improve the quality of their services. Hospitals in Indonesia, especially in the Riau Islands Province, continue to improve. Based on data from the Riau Islands Province Health Office, all regencies and cities have general hospitals now, and they are not only government-owned hospitals but also private hospitals. Their services also continue to improve.
The intense competition between hospitals has become one of the drivers. For example,in Karimun Regency,which is located in the border area of Indonesia, Singapore, and Malaysia,The M. Sani Regional General Hospital is the main choice. The people's gradually improving welfare enables them to choose a hospital that can provide the best service according to their needs. At present, the people in the area do not only go to a government hospital, but they also go to a private hospital and they even go abroad (Malaysia and Singapore).

The M. Sani Regional General Hospital is a government-owned hospital that is motivated to provide excellent service to the people in this area. This hospital continues to improve its quality starting from the budgeting of the equipment,fulfilling the human resources, and providing easy access from people who are from outside the area. This is because an area is a group of islands, and patients must use water vehicles to get to the hospital. The people are certainly grateful to the government for the facilities and the payment method using the Social Security Agency (Badan Penyelenggara Jaminan Sosial/BPJS). Government programs are a form of the government's commitment carried out continuously. 
Such conditions are have been made the government for fostering trust in the government to improve the quality and sustain ability of hospitals in the future. Moreover, with this trust, people who seek treatment at this hospital will not only be the local people but also the people from other areas. In addition, trust can be built from the people's satisfaction in receiving services provided by the hospital.

The data obtained from the M. Sani Regional General Hospital showed that the number of patients who did 'repeat orders' or returned to the hospital,especially inpatient services, increased and decreased. In 2018, there were 1,194 patients who did repeat orders and this number was $30.9 \%$ lower from the previous year which reached 1,728 patients. The opposite was seen in 2016 and 2015 which increased by $13.7 \%$ and the fluctuations indicated that the patient's trust in the hospital was low. Added to this problem was the competition among hospitals, especially the private sector, which were more concerned with quality services and doctors.

Another important image is the attention and encouragement for the patients in following the hospitals' healthcare programs. The question is whether the patients' trust in the services provided by the Karimun Regency government-owned hospital is influenced by the patients' satisfaction with the service, and whether satisfaction is related to responsiveness and providing motivation to patients. This research is to answer the questions, and also to find an effective solution so that government-owned hospitals can compete with private hospitals and even hospitals from Singapore and Malaysia since the people with sufficient funds in this border area can easily find better hospital services.

In the literature review regarding patient satisfaction in receiving services from hospital institutions, Tjiptono (2014) explained that marketing services are directed towards full attention to the customers, because the customers are king, and they need to get quality services. Paul (2011) also explained that marketing services always pursue efficiency and pay attention to profits because this will support the survival of the company and result in the competition. According to Kotler and Keller (2012), it is necessary to have a creative effort in marketing service products because consumer behavior towards these products is very dynamic and customer satisfaction is a major part of winning a competition.

Kotler and Armstrong (2012) asserted that the service marketing mix from the people's side is an important part to consider. According to Ratnasari (2011), people are the most important part of building quality service marketing. Hurriyati (2010) also explained that people play an important role in service marketing. In marketing hospital services, people can provide additional services, such as responsiveness and motivation. The indicators of responsiveness are the results of the synthesis of opinions of Tjiptono (2012), Herlambang (2016), and Hartono (2010), namely greeting patients who come and also introducing themselves to patients.

The variable of motivation given by medical staff is an overview of their readiness to encourage patients who are seeking treatment. As explained by Putranto \& Nyumirah (2012), there is a positive contribution from the motivation given to the patients to the patients' motivation to recover when receiving health services. Muna\& Soleha(2014) stated that in addition to family support, patients need the support from medical staff to calm them when facing pain and to encourage them to recover. Based on the results of synthesis from Kotler and Armstrong (2012), and Hurriyati (2010), the indicators to measure the provision of motivation to patients are: explaining the disease to the patient, explaining honestly the risk of the disease, explaining the prognosis (hope/cure), motivating the patient to recover, and convincing the patient that the disease can be cured.

In addition, there is a connection between responsiveness and providing motivation in the form of service performance. Yuliarmi \& Riyasa (2007) explained that the service responsiveness to the customers has an impact on customer satisfaction. Tho'in (2011) conveyed that the factor of responsiveness affects the satisfaction of financial services customers. Hadiyati (2018) stated that providing motivation to patients in health services by medical personnel will provide satisfaction to patients on the assessment.

According to Zeithaml and Bitner (2011), the customer satisfaction variable is an important part of marketing service products. Patient satisfaction is a form of assessment of what they feel during their time in the hospital. Of the three opinions namely Herlambang (2016), Hartono (2010), and Tjiptono (2012), it can be concluded that patient satisfaction can be measured with indicators of service duration in the service room and equipment completeness in the service room.

Patient trust, associated with hospital services, is a form of an assessment carried out by individuals from the consumption they do. Kanuk and schiffman (2010), Gurviesz (2011), and Garbarino (2012) stated that trust can be measured by indicators of trust in the expertise of the staff, trust in the experience of the staff, trust in the quality of drugs given by the staff; trust in equipment readiness, trust in the staff's insights, and trust in the staff's knowledge.

In terms of satisfaction and trust variables from the responsiveness and motivation variables, Waljee et. al. (2008) found the relationship between satisfaction and trust. Baker, et. al. (2009) conveyed that continuity does not increase satisfaction unless the patient trusts the doctor. Anggraini \& Rohmani (2012) also explained that there is a correlation between satisfactions with trust in receiving treatment at the hospital. 
In relation to the services, this hospital is a referral hospital and comparable to hospitals abroad. The issue of service in this government hospital is part of a discussion that needs a solution. Currently, the medical staff in this government-owned hospital is considered different from medical staff in foreign hospitals. The responsiveness and motivation of foreign hospitals are better than that of the government hospital. Therefore, it can be assumed that responsiveness and motivation provide a significant effect on patient satisfaction and have an impact on the confidence of inpatients in Tanjung Balai Karimun Regency.

\section{METHODS}

The method used in this research is quantitative with a survey technique. This quantitative method includes a descriptive analysis to describe the condition of the research variables and is also associated with the operationalization of the variables by the following definition: responsiveness $\left(\mathrm{X}_{1}\right)$ is in the form of greeting patients who come $\left(X_{1 \_}\right)$and also introduce themselves to patients $\left(\mathrm{X}_{12}\right)$; ;motivation $\left(\mathrm{X}_{2}\right)$ is in the form of explaining the disease to the patient $\left(\mathrm{X}_{21}\right)$, explaining the risk of the disease honestly $\left(\mathrm{X}_{2_{2}}\right)$, explaining the prognosis (hope/healing) $\left(\mathrm{X}_{2_{3} 3}\right)$, motivating the patient to recover $\left(\mathrm{X}_{2_{3}}\right)$, and convincing the patient that the disease can be cured $\left(X_{25}\right)$. For the dependent variables, patient satisfaction (Y) is what is felt by the patient or the patient's family when receiving service with the following indicators: length of service in the service room $\left(\mathrm{Y}_{1_{1}}\right)$ and equipment completeness in the service $\operatorname{room}\left(\mathrm{Y}_{12}\right)$. Then, the patient confidence variable $(\mathrm{Z})$ is a loyal effort to the product with its indicators: trust in the expertise of the staff $\left(Z_{1_{1}}\right)$; trust in the experience of staff $\left(Z_{12}\right)$; trust in the quality of drugs given by the staff $\left(Z_{1_{3}}\right)$; trust in the equipment readiness $\left(Z_{1_{4}}\right)$; trust in the officer's insight $\left(Z_{1}{ }_{5}\right)$; and trust in the officers' knowledge $\left(Z_{1 \_}\right)$.

The population in this research was patients or families of inpatients at M. Sani Regional General Hospital. The patients or patients' families, which were chosen as the population, were those who received inpatient services with a total population of 1,194 people. The questionnaires were given when the patient or the patient's family left the hospital. Because of the relatively large population, the sample size was determined using the Slovin formula. From a minimum sample size of 92 people, 100 patients were decided with a sampling technique using accidental random sampling which is a technique that is used spontaneously when a patient or family of patients is discharged from the hospital.

Questionnaires were used to collect primary data by distributing several questions that are to accommodate the patients' opinions regarding the service that they had received, whether they were satisfied with the service both in terms of the responsiveness of the medical staff and the ability of medical staff to provide consultation and convince the patients about the disease. The questionnaire was made based on the operationalization of variables from the theory used mentioned in this research.

SEM program was used based on the consideration that it is an integrated approach from the existing model and also simpler in understanding the results of existing research. Calculations were done using five existing scores divided by four criteria, each of 0.8 , then the interval 1 to 1.8 was categorized as very poor, 1.81 to 2.60 as poor, 2.61 to 3.40 as fairly good, 3.41 to 4.20 as good, and above 4.21 as very good.

\section{RESULTS}

Based on data collected and processed using Warp PLS and analyzed using SEM analysis tools, the following data can be described. The description of the research results relates to the characteristics of the respondents and also illustrates the research variables. The respondents' age provided an overview of their experiences in choosing a hospital for treatment. Their experience illustrated the hospital in providing inpatient services. Table 1 is a description of the respondents' age.

Table 1 shows that the majority of respondents were aged over 50 years, amounted to $36 \%$. When viewed from the data, it can be asserted that based on the age of the respondents, the inpatients who were treated at the Riau Islands Hospital are of a reasonable age in providing an assessment of services, satisfaction, medical performance and also their trust in what is provided by the hospital. The people who were under 20 years old were basically those who were hospitalized and brought by their relatives or family so that they only followed their parents in choosing the regional general hospital as their place of treatment.

The level of education of the respondents provided a basic view of the knowledge and insight of the patients in providing an assessment of what they know. The higher the patients' education, the more extensive their knowledge and insight about the quality of service that they should receive. Table 2 is a description of the respondents' education level.

Table 2 shows that the majority of respondents had senior high school/vocational high school education $(43.00 \%)$. The low education level of the respondents showed that their knowledge and insight in assessing the services of regional general hospitals were limited. This was also a form of the respondents' unique characteristics in the research as limited educational conditions resulted in them only following what was given by the hospital.

The respondents by gender provided a detailed description of the treatment given to male patients and female patients. Gender also provided information 
about the accuracy of the services, because females have the sensitivity for service problem. The data of respondents based on gender is described in Table 3 .

Table 3 shows that the majority of the respondents were females $(58 \%)$. In accordance with the importance of gender in the assessment of service quality provided by government-owned hospitals in Riau Islands Province, respondents can provide realistic information, so that the data can provide conclusions according to the results of the study.

Validity and reliability tests and normality test were used to ensure the steps in the SEM meet existing requirements. First, the validity test turned valid results as the lowest value was 0.37 and the highest value was 1.78 because the rcount value was greater than the critical value of 0.30 . While for the reliability test, the Cronbach alpha value for the responsiveness was 0.72 , the motivation given to patients was 0.82 , satisfaction was 0.71 , and trust was 0.87 . The values were greater than the standard 0.60 ,which indicated that all variables were reliable. For the data normality test, it as found that the value of $X_{1}=0.16, X_{2}=0.13$, $\mathrm{Y}=0.14$, and $\mathrm{Z}=0.12$, thus the figure was compared with 0.05 in the normal category.

The descriptive analysis of the responses to the questionnaire is related to describing the research variables. The responsiveness variable used two indicators showed in Table 4.

Table 4 shows that the respondents' answers had an average score of 3.13 , which was fairly good. This indicates that the responsiveness of patients or family of patients to medical services was good enough in which the highest score was obtained by greetings the patients who come and the lowest was by introducing themselves to patients before giving service.

The motivation variable with five indicators namely explaining the disease to the patient, explaining the risk of the disease honestly, explaining the prognosis (hope/healing), motivating the patient to recover, and convincing the patient that the disease can be cured, can be seen in Table 5 .

Table 5 show that the motivation for the patients had an average score 3.32, which indicates that the patients had given a fairly good response, and this is shown by the highest response namely in explaining the risk of the disease to the patient and the lowest in convincing the patient that the disease can be cured, which was still lacking.

Furthermore, for the dependent variables namely patient satisfaction with the indicators of the duration of service in the room and the completeness of the equipment in the room, the description is presented in Table 6.

Table 6 shows that patient satisfaction in the service of inpatient doctors had an average score of 3.21, and it was in the fairly good category. This indicates that the patient or family of patients gave fairly good responses where the highest items namely in the completeness of equipment in the service room and the lowest in the length of service provided in the service room.

The patient trust variable had indicators of trusts in the expertise of the staff, trust in the experience of the staff, trust in the quality of the drug provided by the staff, trust in the readiness of the equipment, trust in the insight of the staff, and trust in the knowledge of the staff. The description of patient trust variables is presented in Table 7 .

Table 7 shows that the patient trust in medical staff who provided services at M Sani Regional General Hospital gained an average score of 3.29 which was fairly good. From the five indicators, the highest indicator was identified, namely the waiting room that was adequate and the lowest indicator was the time of service.

The results of the verification analysis showed that there was a significant influence both directly and indirectly from the responsiveness variable and also the provision of motivation to patients on patient satisfaction receiving services at the $\mathrm{M}$. Sani Regional General Hospital in Tanjung Balai Karimun. Then the satisfaction that the patient felt proved to have a significant effect on the trust in the inpatient treatment at the government-owned hospital. More details of the is presented in Figure 1.

From the results of data processing using SEM analysis tools and processed with the Warp PLS application, it can be seen that the influence of responsiveness to patient satisfaction had a P-Value of 0.01 , which means a significant effect and a $\beta$ value of 0.20 indicating a positive effect. Then, the variable of motivation for patients by medical staff had a P-Value of 0.01 , which means a significant effect and a $\beta$ value of 0.42 . From these two variables, it was also evident that the variable of motivation had more influence than the responsiveness of medical staff $(0.42>0.20)$. The resulting equation model is as follows:

$$
\eta_{1}=0.20 * \xi_{1}+0.42 * \xi_{2},+\zeta_{1}, \mathrm{R}^{2}=0.31
$$

The effect of patient satisfaction on patient confidence had a P-Value of 0.01 , which means a significant effect and $\beta$ value of 0.55 and this showed that patient satisfaction had a significant and positive effect on the confidence of inpatients at M. Sani Regional General Hospital. The resulting equation model is as follows:

$$
\eta_{2}=0.55 * \xi_{1}+\zeta_{2}, R^{2}=0.30
$$

It can also be seen that the effect of responsiveness and motivation for patients was $31 \%$ on patient satisfaction, while the patient satisfaction variable had an effect of $30 \%$ on the trust of inpatients from the assessment made on the services that they had received. 


\section{DISCUSSION}

The responsiveness and motivation provided by the medical staff for the patients were directed towards the attention of the medical staff before providing health services. Responsiveness was proven to have a significant effect on patient satisfaction and the same results were gained by providing motivation for patients that had a significant influence on patient satisfaction. The results of this research are in line with what was stated by Alrubaiee \& Alkaa'ida (2011) and also Naseer, et. al. (2012) that patients' perceptions of medical staff have an impact on satisfaction. Chang, et. al. (2013) and Shan, et. al. (2016) also stated that quality services such as those from the staff have an impact on patient satisfaction. Wu (2011) and Seiler, et. al. (2012) explained that the image of the hospital from medical staff helped build patient satisfaction.

Based on the data, it is proven that giving motivation to patients had a greater effect on satisfaction when compared to the responsiveness of the medical staff in providing services to their patients. This showed that it is important to provide motivation to patients, so that the patients feel that they have hope of recovery in treatment at the hospital. This condition also gives a suggestion to the patient to foster enthusiasm for recovery. In line with Tang (2011), attitudes in serving patients have an impact on satisfaction. This was also confirmed by Simons, et. al. (2014) that providing understanding to patients will make patients know the real condition that is felt in receiving services. Aiken, et. al. (2018) also said that the care of medical personnel will make patients calm. Zineldin (2015) also emphasized that caring in giving encouragement to patients is one of the factors resulting in patient satisfaction. Aliman \& Mohamad (2013) also gave their views that the patient's perception of the service of a medical staff has an impact on satisfaction in receiving service.

The condition of the patient not being ready to accept the reality of the disease and the risks that will be faced is a reason for the medical staff to be less willing to openly convey clearly the patient's illness. In addition, the efforts of the medical staff to help cure the patients suffering from illnesses by providing motivation and appropriate medication and directives are really needed by the patients. Patients also feel quite clear with what is explained by the medical staff about what they have to do in an effort to cure the patients' illnesses.

The medical staff, in the efforts to motivate patients to recover from their illnesses, always provide good things in the form of the development of healing and always encourage patients to pray in their psychological endeavors. Efforts that encourage patients to stay motivated and also have hope for recovery are always given by the medical staff. Some medical staff sometimes do not have a perfect presentation of what patients should receive because of their limited ability to explain.
The mismatch between the number of medical staff and the number of patients served causes the medical staff to divide their time and always seem to be in a hurry to provide services. Seeing the condition of the imbalance of the number in hospital services causes the service to be imperfect. In addition, medical staff also try to convince patients or their families about the hope of healing the illnesses suffered by patients.

Efforts to cure patients become a real hope and responsibility of medical staff in health services. Various efforts to entertain patients, such as telling stories about the success of patients in fighting the disease are made by medical officers. This also becomes a form of the medical staff's empathy in serving their patients well.

In turn, patient satisfaction has an impact on patient trust in the services provided by the hospital. This is in line with what is stated by Shabbir, et. al. (2010) and $\mathrm{Wu}$, et. al. (2016). It is also confirmed by Tang (2013) and also Ommen, et. al. (2011), Khodadad Hosseini \& Behboudi (2017) and Naseer Zahidie \& Shaikh (2012) that efforts to satisfy patients in service will have a positive impact on trust.

Based on the description of the medical staff in this research, the overall the medical staff at the regional general hospital for inpatient services in Riau Islands Province are in the category of fairly good to good. It is also known that the highest dimension item is in the dimension of carrying out a physical examination and explaining the patient's prognosis (hope or counseling). Therefore, medical personnel in providing services to inpatients prioritize their main tasks in examining and also giving hope of healing to patients compared to other services.

Furthermore, this matter can also be explained by the efforts to respond to various complaints felt by the patient. Doctors in greeting and introducing themselves in improving their medical performance always try to emphasize the friendliness to patients. The lowest value of this dimension is the indicator "Introducing themselves to the patient", which shows that doctors in hospitals in Riau Islands Province have not been able to show hospitality to patients. Doctors are not optimal in greeting the inpatients. It was felt by the patient that the doctor came in then saw the patient's condition and then left. Basically, the patients wanted to communicate with the doctors and talk about problems and illnesses experienced by patients. The patients also want to be more convinced of their hopes of recovery. The desire to recover by the patient coupled with the explanation given by the doctor to the patient will foster enthusiasm for recovery by the patients themselves. However, the doctor, who the patients were waiting for, only came for a short time, talked with unfriendly expressions, and left quickly can discourage the patient.

The medical staff rarely wants to introduce themselves. They only examine the patient and fewer 
pleasantries are delivered. Meanwhile, the hospital has a slogan of the concept of 5S (senyum (smile), sapa (greetings), salam (greetings and praying), sopan dan santun (politeness and courtesy). This concept is applied to give the inpatients get comfort and the feel of friendliness and attention. This is a simple wish and every medical staff can carry it out. When seen from the real conditions of the limited number of medical staff while there is an overwhelming need, some medical staff open their own practice and there are even those who work late at night to carry out medical operations. However, this condition becomes their obligation, and it has been their duties.

\section{CONCLUSIONS}

Based on the results of the research, it was proven that medical staff who are responsive to patients and also give motivation to patients will satisfy patients with the services provided. This patient satisfaction has a significant effect on patient trust in inpatient services at M. Sani Hospital Tanjung Balai Karimun. A positive and better impact can be achieved if the leaders of the health service institution make the medical staff as a basis in order to increase patient trust and satisfaction.

\section{ACKNOWLEDGMENTS}

Thank you to the leadership of the Faculty of Economics, Universitas Lancang Kuning for providing financial support, and also Universitas Pasundan for their willingness to collaborate on this research to produce this article about service marketing.

\section{REFERENCES}

Aiken, L. H., Sloane, D. M., Ball, J., Bruyneel, L., Rafferty, A. M., \& Griffiths, P. 2018. Patient satisfaction with hospital care and nurses in England: an observational study. BMJ open, 8(1), e019189.

Aliman, N. K., \& Mohamad, W. N. 2013. Perceptions of service quality and behavioral intentions: A mediation effect of patient satisfaction in the private health care in Malaysia. International Journal of Marketing Studies, 5(4), 15.

Alrubaiee, L. and Alkaa'ida, F., 2011. The mediating effect of patient satisfaction in the patients' perceptions of healthcare quality-patient trust relationship. International Journal of Marketing Studies, 3(1), p.103.

Anggraini, M.T. and Rohmani, A., 2012. Hubungan kepuasan pasien dengan minat pasien dalam pemanfaatan ulang pelayanan kesehatan pada praktek dokter keluarga. In Prosiding Seminar Nasioanal \& Internasional (Vol. 1, No. 1).

Baker, R., Mainous Iii, A.G., Gray, D.P. and Love, M.M., 2003. Exploration of the relationship between continuity, trust in regular doctors and patient satisfaction with consultations with family doctors. Scandinavian journal of primary health care, 21(1), pp.27-32.

Chang, C. S., Chen, S. Y., \& Lan, Y. T. 2013. Service quality, trust, and patient satisfaction in interpersonal-based medical service encounters. BMC health services research, 13(1), 22.

Garbarino dan Johnson. 2012.The Different Roles of Satisfaction, Trust, and Commitment in Customer Relationship. Journal of Marketing, 63-70

Gurviesz \& Korchia. 2011. Marketing fields forever, Kingston Business School, Liverpool

Hadiyati. 2018. Pengaruh Kinerja Medis dan Pelayanan Terhadap Kepuasan dan Implikasinya Pada Kepercayaan Pasien Rawat Inap pada RSUD di Propinsi Kepulauan Riau (Doctoral dissertation, Unpas).

Hartono, Bambang. 2010. Manajemen Pemasaran Untuk Rumah Sakit. Rineka Cipta, Jakarta.

Herlambang, Susatyo. 2016. Manajemen Pelayanan Kesehatan Rumah Sakit, Gosyen Publishing, Yogyakata.

Hurriyati, Ratih. 2010. Manajemen Corporate dan Strategi Pemasaran Jasa Pendidikan. Alfabeta. Bandung.

Kanuk and Schiffman. 2010. Perilaku Konsumen. Edisi Kedua. Jakarta. PT. Indeks Gramedia

Khodadad Hosseini, S. H., \& Behboudi, L. 2017. Brand trust and image: effects on customer satisfaction. International journal of health care quality assurance, 30(7), 580-590.

Kotler and Keller. 2012. Manajemen Pemasaran. Edisi 13 Jilid 2. Erlangga. Jakarta.

Kotler dan Amstrong. 2012. Prinsip-prinsip Pemasaran, alih bahasa Damos Sihombing, Jilid 2, Edisi Kedelapan. Erlangga. Jakarta.

Muna, L., \& Soleha, U. 2014. Motivasi Dan Dukungan Sosial Keluarga Mempengaruhi Kepatuhan Berobat Pada Pasien TB Paru Di Poli Paru Bp4 Pamekasan. Journal of Health Sciences, 7(2).

Naseer, M., Zahidie, A., \& Shaikh, B. T. 2012. Determinants of patient's satisfaction with health care system in Pakistan: a critical review. Pakistan Journal of Public Health, 2(2), 52.

Ommen, O., Thuem, S., Pfaff, H., \& Janssen, C. 2011. The relationship between social support, shared decision-making and patient's trust in doctors: a cross-sectional survey of 2,197 inpatients using the Cologne Patient Questionnaire. International journal of public health, 56(3), 319-327.

Paul D. Converse. 2011. Elements of marketing, sixth edition Englewood-Cliffs,. New Jersey: prentice Hall Inc.

Putranto, D. A., \& Nyumirah, S. 2012. Pengaruh Pemberian Motivasi Spiritual Terhadap Penurunan Tingkat Depresi Pasien Hemodialisa di RSUD dr. 
R. Soetrasno Rembang. Jurnal Keperawatan dan Kesehatan Masyarakat Cendekia Utama, 1(1).

Ratnasari. 2011. Manajemen Pemasaran Jasa. Bogor, Ghalia

Seiler, A., Visintainer, P., Brzostek, R., Ehresman, M., Benjamin, E., Whitcomb, W., \& Rothberg, M. B. 2012. Patient satisfaction with hospital care provided by hospitalists and primary care physicians. Journal of hospital medicine, 7(2), 131-136.

Shabbir, S., Kaufmann, H. R., \& Shehzad, M. 2010. Service quality, word of mouth and trust: Drivers to achieve patient satisfaction. Scientific research and Essays, 5(17), 2457-2462.

Shan, L., Li, Y., Ding, D., Wu, Q., Liu, C., Jiao, M., Hao, Y., Han, Y., Gao, L., Hao, J. and Wang, L., 2016. Patient satisfaction with hospital inpatient care: effects of trust, medical insurance and perceived quality of care. PloS one, 11(10).

Simons, Y., Caprio, T., Furiasse, N., Kriss, M., Williams, M. V., \& O'Leary, K. J. 2014. The impact of facecards on patients' knowledge, satisfaction, trust, and agreement with hospital physicians: a pilot study. Journal of hospital medicine, 9(3), 137-141.

Tang, L. 2011. The influences of patient's trust in medical service and attitude towards health policy on patient's overall satisfaction with medical service and sub satisfaction in China. BMC Public Health, 11(1), 472.

Tang, L. 2013. The Chinese community patient's life satisfaction, assessment of community medical service, and trust in community health delivery system. Health and quality of life outcomes, 11(1), 18.

Tho'in, M. 2011. Pengaruh Faktor-faktor Kualitas

Table 1. Respondents based on Age

\begin{tabular}{cccc}
\hline No & Age & Number & Percentage \\
\hline 1 & $<30$ & 17 & $17.0 \%$ \\
2 & 31 to 40 & 26 & $26.0 \%$ \\
3 & 41 to 50 & 21 & $21.0 \%$ \\
4 & $>51$ & 36 & $36.0 \%$ \\
\hline & Total & 100 & $100.0 \%$ \\
\hline
\end{tabular}

Source: Processed data

Table 2. Respondents based on Education Level

\begin{tabular}{clcc}
\hline No & \multicolumn{1}{c}{ Education } & Number & Percentage \\
\hline 1 & Elementary School & 17 & $17.0 \%$ \\
2 & Junior High School & 20 & $20.0 \%$ \\
3 & Senior/Vocational High School & 43 & $43.0 \%$ \\
4 & Higher Education & 20 & $20.0 \%$ \\
\hline & Total & 100 & $100.0 \%$ \\
\hline
\end{tabular}

Source: Processed data
Jasa terhadap Kepuasan Nasabah di Baitul Mal Wat Tamwil (BMT) Tekun Karanggede Boyolali. Muqtasid: Jurnal Ekonomi dan Perbankan Syariah, 2(1), 73-89.

Tjiptono, Fandy. 2012. Service Management Mewujudkan Layanan Prima. CV Andi Offset: Yogyakarta.

Tjiptono, Fandy. 2014. Pemasaran Jasa. Jakarta: Gramedia

Waljee, J.F., Hu, E.S., Newman, L.A. and Alderman, A.K. 2008. Correlates of patient satisfaction and provider trust after breast-conserving surgery. Cancer: Interdisciplinary International Journal of the American Cancer Society, 112(8), pp.16791687.

Wu, C. C. 2011. The impact of hospital brand image on service quality, patient satisfaction and loyalty. African Journal of Business Management, 5(12), 4873-4882.

Wu, H. C., Li, T., \& Li, M. Y. 2016. A study of behavioral intentions, patient satisfaction, perceived value, patient trust and experiential quality for medical tourists. Journal of Quality Assurance in Hospitality \& Tourism, 17(2), 114-150.

Yuliarmi, N. N., \& Riyasa, P. 2007. Analisis faktorfaktor yang mempengaruhi kepuasan pelanggan terhadap pelayanan PDAM Kota Denpasar. Buletin Studi Ekonomi, 12(1), 9-28.

Zeithaml dan Bitner. 2011. Service Marketing. McGrawhill:New York.

Zineldin, M. 2015. Determinants of patient safety, satisfaction and trust: with focus on physiciansnurses performance. Clinical Governance: An International Journal, 20(2), 82-90.

Table 3. Respondents based on Gender

\begin{tabular}{cccc}
\hline No & Gender & Number & Percentage \\
\hline 1 & Male & 42 & $42.0 \%$ \\
2 & Female & 58 & $58.0 \%$ \\
\hline & Total & 100 & $100.0 \%$ \\
\hline
\end{tabular}

Source: Processed data

Table 4. Description of Responsiveness Variable at M. Sani Regional General Hospital

\begin{tabular}{ccccccccc}
\hline No & Responsiveness & 5 & 4 & 3 & 2 & 1 & Average & Category \\
\hline 1 & $\begin{array}{l}\text { Greet patients who } \\
\text { come }\end{array}$ & 20 & 125 & 78 & 43 & 34 & 3.18 & Fairly Good \\
2 & $\begin{array}{l}\text { Introduce themselves } \\
\text { to the patients }\end{array}$ & 35 & 103 & 55 & 68 & 39 & 3.09 & Fairly Good \\
\hline & Average Score & & & & & 3.13 & Fairly Good
\end{tabular}

Source: Processed data. 
Table 5. Description of Motivation for Patients Variable at M. Sani Regional General Hospital

\begin{tabular}{|c|c|c|c|c|c|c|c|c|}
\hline No & Motivation & 5 & 4 & 3 & 2 & 1 & Average & Category \\
\hline 1 & $\begin{array}{l}\text { Explain the disease to } \\
\text { patients }\end{array}$ & 37 & 139 & 74 & 29 & 21 & 3.47 & $\begin{array}{l}\text { Fairly } \\
\text { Good }\end{array}$ \\
\hline 2 & $\begin{array}{l}\text { Explain the risks of the } \\
\text { disease honestly }\end{array}$ & 38 & 123 & 86 & 34 & 19 & 3.42 & $\begin{array}{l}\text { Fairly } \\
\text { Good }\end{array}$ \\
\hline 3 & $\begin{array}{l}\text { Explain the prognosis } \\
\text { (hope/cure) }\end{array}$ & 18 & 135 & 71 & 62 & 14 & 3.27 & $\begin{array}{l}\text { Fairly } \\
\text { Good }\end{array}$ \\
\hline 4 & $\begin{array}{l}\text { Motivate patients to } \\
\text { recover }\end{array}$ & 31 & 114 & 79 & 53 & 23 & 3.25 & $\begin{array}{l}\text { Fairly } \\
\text { Good }\end{array}$ \\
\hline 5 & $\begin{array}{l}\text { Convince the patient that } \\
\text { the disease can be cured }\end{array}$ & 14 & 149 & 60 & 44 & 33 & 3.22 & $\begin{array}{l}\text { Fairly } \\
\text { Good }\end{array}$ \\
\hline & Average score & & & & & & 3.32 & Fairly Good \\
\hline \multicolumn{9}{|c|}{$\begin{array}{l}\text { Table 6. Description of Patients Satisfaction Variable at M. Sani } \\
\text { Regional General Hospital }\end{array}$} \\
\hline No & Patient Satisfaction & 5 & 4 & 3 & 2 & 1 & Average & Category \\
\hline 1 & $\begin{array}{l}\text { Duration of service } \\
\text { in the room }\end{array}$ & 10 & 83 & 91 & 72 & 40 & 2.83 & Fairly Good \\
\hline 2 & $\begin{array}{l}\text { Completeness of } \\
\text { equipment in the room }\end{array}$ & 26 & 113 & 117 & 39 & 1 & 3.42 & Good \\
\hline & Average score & & & & & & 3.21 & Fairly Good \\
\hline
\end{tabular}

Table 7. Description of Patients Trust Variable at M. Sani Regional General Hospital

\begin{tabular}{clccccccc}
\hline No & Patient Trust & 5 & 4 & 3 & 2 & 1 & Average & Category \\
\hline 1 & Time of service & 14 & 114 & 101 & 37 & 34 & 3.12 & Fairly Good \\
2 & Waiting room & 19 & 131 & 139 & 10 & 1 & 3.52 & Good \\
3 & Doctor's attitude & 26 & 127 & 74 & 59 & 14 & 3.30 & Fairly Good \\
4 & Prescription given & 22 & 129 & 72 & 63 & 14 & 3.27 & Fairly Good \\
5 & Service time by the & 33 & 125 & 70 & 39 & 33 & 3.28 & Fairly Good \\
& nurse & & & & & & & \\
\hline & Average score & & & & & 3.29 & Fairly Good \\
\hline
\end{tabular}

Source: Processed data.

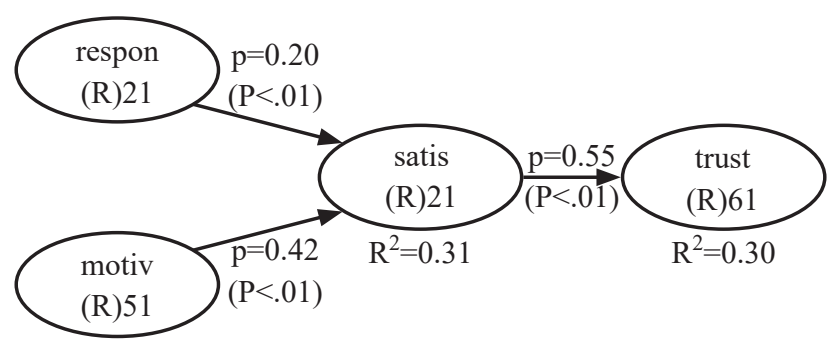

Figure 1. Full Model of the Effect of Responsiveness of and Motivation for Patients

Source: Processed data. 